\title{
Mirrors of/for the Times: Shakespeare in Central European Theatre
}

\author{
Filip Krajník
}

Jana Bžochová-Wild (ed.). Zrkadlá (pre) doby. Shakespeare v divadle strednej Európy. Bratislava: Academy of Performing Arts, 2015. 186 pp.

In the same vein as Jana BžochováWild's previous volume, In Double Trust (KOSTIHOVÁ 2014: 238-240), Zrkadlá (pre) doby (Mirrors of/for the Times) charts how Shakespeare's works assumed the role of an active participant in the cultural and political history (or, rather, histories) of the Central European region (today's Austria, Poland, Hungary, Czech Republic and Slovakia). Unlike its predecessor, Zrkadlá focuses solely on the theatrical reception of Shakespeare, perhaps with the exception of Jacek Fabiszak's essay on a television adaptation of a Yugoslavian play, in the course of the past 100 years. For the Central European nations, who often found themselves at the mercy of more dominant cultures both from the East and the West, the $20^{\text {th }}$ century was an especially turbulent period. It began with the region's various states' political emancipation at the end of the First World War, but was soon followed by a period of two totalitarian regimes, Nazism and Communism. The collapse of the Communist dictatorship in the Eastern Bloc and the newly gained political, social and economic liberties, however, did not manage to end the traumas and conflicts of the past, which will probably take several more decades to fully come to terms with. Moreover, as Gabriella Reuss's study points out, a new generation of theatrego- ers has appeared, which often has little patience for classics and traditional theatrical techniques, thus posing new challenges for contemporary theatre practitioners. Bžochová-Wild's volume shows how, in the past century, Shakespeare has served not only as a tool for resistance, especially in the most critical moments in the individual nations' histories, but also as a form of cultural memory, which gives a testimony of - or, to use the volume's Shakespearean terminology, holds up a mirror up to - the moral state of society.

Although the volume is not divided into thematic sections, the twelve studies are arranged according to the national cultures which they address. It starts with Ludwig Schnauder's discussion of one of the most blatant misuses of Shakespeare by Nazis in WWII Austria (in the production of The Merchant of Venice by Lothar Müthel at the Vienna Burgtheater in 1943); it finishes with Bžochová-Wild's own survey of Shakespearean productions in Communist Slovakia, particularly focusing on the 1978 production of Love's Labour's Lost by Miloš Pietor, which, in a way, both subverted and supported the then official regime. Besides the analyses of how Shakespeare's words resonated against moments of both critical change in, and stagnation of, individual country's societies (which, despite 
their geographical closeness, each underwent a different development), the studies in the volume also address the issues of genre, form and place, which significantly contributed to the overall effect of the productions on their respective audiences. The hic et nunc character of theatre becomes clearly apparent. Thus Jacek Fabiszak's text explains how an Elizabethan drama became the basis of the 1970s antiCommunist play by the Croatian dramatist Ivo Brešan, which was subsequently adapted within the framework of Polish 'television theatre' of the mid-1980s. Aleksandra Sakowska's essay shows how the Gdansk Shipyard, a symbol of Poland's resistance against the former Communist regime, as well as the disillusion after its ultimate fall, lent new meaning to Shakespeare's text when the place was transformed into the stage of Jan Klata's 2004 adaptation of Hamlet. Eva Kyselová discusses the specifics of the Czech author Pavel Kohout's famous adaptation of Shakespeare's Macbeth, which was produced in 1978 by Vlasta Chramostová's Apartment Theatre. (This event, which was one of the most visible manifestations of dissident subculture in Communist Czechoslovakia of the period of the so-called 'Normalisation', shortly afterwards became the source for Tom Stoppard's 1979 play Cahoot's Macbeth).

Despite the undeniable merit of the individual studies and the editor's effort to stress the overarching themes in the closing chapter, Zrkadlá, sadly, remains not much more than the sum of its parts. Although, in the Introduction, the editor stresses the differences between the reception histories of Shakespeare in the individual countries (9), the abovementioned arrangement of the chapters invites the reader to read the reception(s) of Shakespeare strictly within the boundaries of the national states rather than the region as a whole, whose shared commonalities are never stressed or, indeed, explicitly pointed out. One may therefore ask why the editor opted for the five countries included in the volume? And how the book would be different if, let us say, Austria were replaced by the Baltic countries or the former Yugoslavia? The individual authors never refer to each other and it appears that, when writing the texts, they were probably not fully aware of the other topics that the volume would address. Thus, when Eva Kyselová opens her discussion of Kohout's Play Makbeth, claiming that Shakespeare's plays played an important role in Czech theatre culture, her words sound somewhat awkward immediately after Ivona Mišterová's detailed account of the 1916 Shakespearean festival in Prague, which became a manifestation of the Czechs' desire for cultural and political independence.

Overall, however, Zrkadlá represents a laudable endeavour, aimed at mapping out how Shakespeare, in various forms, functioned within the central European geopolitical sphere, focusing not only on the texts of Shakespeare's plays and specific productions, but also on the contexts in which these were performed and staged. These, on the one hand, are crucial for an informed reading of how Shakespeare managed to address the audiences of the periods, yet may remain obscure for an early $21^{\text {st }}$ century reader, especially a younger one. The volume is also the first of its kind in the Slovak and Czech language (10 of the 12 studies are in Slovak, the remaining 2 are in Czech), by which Slovak and Czech 
readers are finally given a history of the Bibliography modern reception of Shakespeare within their cultural region. Such an endeavour KOSTIHOVÁ, Marcela. 2014. In double trust: has long been overdue and, as such, surely deserves recognition. Shakespeare in Central Europe. Theatralia 17 (2014): 2: 238-240. 